doi:10.4149/neo_2017_108

\title{
Decreased expression of MS4A12 inhibits differentiation and predicts early stage survival in colon cancer
}

\author{
L. HE ${ }^{1, \neq}$, H. Y. DENG ${ }^{1, *}$, X. C.WANG ${ }^{1, *}$ \\ ${ }^{1}$ Department of Medical Laboratory, Xiangya School of Medicine, Central South University, Changsha 410013, China \\ ${ }^{*}$ Correspondence: 810768205@qq.com \\ ${ }^{*}$ Contributed equally to this work
}

Received July 4, 2016 / Accepted September 12, 2016

\begin{abstract}
Lack of normal differentiation was considered as a common defect in cancer cells. MS4A12, a colon-specific gene, belongs to MS4A family that plays an important role in differentiation, proliferation and cell cycle regulation. The aim of the study was to investigate MS4A12 role in colon cancer cell differentiation and its prognostic value in colon cancer. We used sodium butyrate (BS) to set up differentiated model of colon cancer cell line LoVo. Cell differentiation was evaluated with ALP activity and E-cadherin. We used BS ( $4 \mathrm{mmol} / \mathrm{L})$ inducing differentiation of LoVo cell and found after BS treated over 48h MS4A12 variant-1 (one of MS4A12 gene transcripts) as well as ALP and E-cadherin of LoVo cells were all increased significantly. When silence MS4A12 variant-1, the elevation of ALP and E-cadherin in BS-treated cells were all inhibited. Besides, after silence MS4A12 variant-1, the cells showed significant resistances to BS function of induction cell cycle arrest and apoptosis. Survival analysis used GEO datasets GSE39582 and GSE38832 that include 681 distinct colon cancer samples. Log-rank test and Cox's proportional hazards regression were applied to analyzing single and multiple prognostic variables, respectively. In early stage colon cancer, the patients with low MS4A12 expression had a poor survival $(\mathrm{HR}=1.72 ; \mathrm{p}=0.036)$, while in advanced stage colon cancer MS412 had little prognostic value $(\mathrm{HR}=0.89 ; \mathrm{p}=0.601)$. These results indicated MS4A12 might relate to colon cancer cell differentiation and supposed to be a risk classification marker for early stage colon cancer.
\end{abstract}

Key words: colon cancer, differentiation, prognosis, MS4A12

Lack of normal differentiation is one of the most important traits of colon cancer cells. The low differentiated colon tumor usually showed strong chemoradiotherapy resistance and high recurrence [1], so study on differentiation mechanism of colon cancer is vital to its pathogenesis, diagnosis and treatment. MS4A (membrane-spanning 4-domain family, subfamily A) family is a new superfamily distinguished from well - characterized tetraspanin superfamily [2, 3]. MS4A family contains a group of cell surface proteins, which typically have tetraspanning topology [4]. MS4A genes are clustered on Chromosome 11q12 in human (chromosome 19 in mice), that region is related to allergy and atopy [4-6]. MS4A genes first appeared in cartilaginous fish, the earliest vertebrates, and the orthologs of human MS4A genes were only found in mammals, which indicated they could have some specific effects on advanced function of mammals [5]. There are at least 16 MS4A family members in human [5], including MS4A1
(CD20), MS4A2 (FceRI), MS4A3 (Htm4), MS4A4A, MS4A4E, MS4A5, MS4A6A, MS4A6E, MS4A7 (CFFM4), MS4A8B, MS4A10, MS4A12, MS4A13, MAS414, MS4A15 and MS4A18 [7-10]. Currently, the functions of most of MS4A proteins are not well clear, but generic evidences suggest that they are comprised of a group of adaptor proteins/ion transport modulators with likely diverse roles $[5,11]$. MS4A1 (CD20) is the first defined MS4A gene, which is limited expressing in B lymphocyte and lymphoma cell, thus becoming a vital target for immunotherapy of lymphoma and leukemia [12-15]. MS4A1 is a store-operated calcium channel on the surface of B lymphocyte with important function on the regulation of differentiation, proliferation and development [7, 16-18]. Most of MS4A members share a relatively high polypeptide sequence identity to that of MS4A1 (20-32\% similarity), so they are also defined as CD20-like family [19]. Subsequently, the functions of MS4A2 (FceRI 3 ), MS4A3 (HTm4) and MS4A7 (CFFM4) 
were defined in immune and hematopoietic cells $[9,10,20]$. Recently, MS4A6E, MS4A8B (L985P) and MS4A12 were also reported to expression in solid tissues and related to certain diseases, such as Alzheimer's disease, prostate cancer, lung cancer and colon cancer [21-26].

MS4A12, structurally similar to MS4A1, is a colon-specific gene [24]. Functionally like store-operated calcium channel, MS4A12 is specifically expressed in apical membrane of colonic epithelium and related to proliferation and motility of colon cancer cells [24]. In vitro, MS4A12 was found to be directly regulated by CDX2 [26], an intestinal tumor suppressor determining differentiation of gut epithelium [27]. In colon adenoma and carcinoma, mRNA expression of two MS4A12 transcripts (MS4A12 variant-1 and MS4A12 variant-2) were significantly decline compared to normal colon [27]. Transcript variants of MS4A members can be translated into different isoforms with distinct functions, and different expression of the splice variants suggests a new mechanism of regulation [8, 28-30]. Although two splice variants of MS4A12 have been identified, the functions of these variants were not defined.

The present studies showed MS4A12 is a colon-specific gene regulated by intestinal differentiation transcription factor CDX2, but still lack the direct evidence to prove MS4A12 function on differentiation of colon cell and its clinical value. In this study we used sodium butyrate to induce differentiation of colon cancer cell line LoVo [31, 32], and then investigate the role of MS4A12 variants on differentiation. Besides, this study also discussed prognosis value of MS4A12 in colon cancer patient with different clinical stages.

\section{Materials and methods}

Cell culture. Colon cancer cell line LoVo was purchased from cell bank of Advanced Studies Department, Central South University. Cells were maintained in RPMI 1640 containing $10 \% \mathrm{FBS}$ and $1 \% \mathrm{~L}$-glutamine and incubated at 5\% $\mathrm{CO}_{2}, 37^{\circ} \mathrm{C}$. Sodium butyrate (Sigma, USA) was added to culture medium at final concentration of $1 \mathrm{mmol} / \mathrm{L}, 2 \mathrm{mmol} / \mathrm{L}$ and $4 \mathrm{mmol} / \mathrm{L}$.

RNA extraction, reverse transcription-PCR and real time-PCR. Total RNA were extracted by trizol (MRC, USA). Purity and concentration of total RNA were analyzed by UV spectrophotometer. The OD $260 \mathrm{~nm} / \mathrm{OD} 280 \mathrm{~nm}$ of the total RNA were between 1.8 and 2.0. Reverse transcription PCR used HiScript II 1st Strand cDNA Synthesis Kit (Vazyme, China) according to manufacturer's instructions. Two MS4A12 primer pairs amplified two MS4A12 transcripts, MS4A12 variant-1 (sense, 5'-gcaaaggcactaggggtgatcca-3'; antisense, 5 '-ggccaccccagaatgggtatcca- 3 ; $55^{\circ} \mathrm{C}$ annealing) [27] and MS4A12 variant-2 (sense , 5 '-ggcactagggtttattatctctggc-3'; antisense, 5'-tcccaggctgcctttcaccag- $3^{\prime} ; 53^{\circ} \mathrm{C}$ annealing) [27], together with a primer pair for reference gene GAPDH (sense, 5'-gaaggtgaaggtcggagt-3'; antisense, 5 '-gaagatggtgatgggatttc- 3 '; $55^{\circ} \mathrm{C}$ annealing). Real time-PCR was analyzed by StepONE- plus (Applied Biosystems, UK) using AceQ qPCR SYBR Green Master Mix (Vazyme, China).

RNA interference. Two small interfering RNA ( $\mathrm{Ri}$ bobio, Guangzhou, China) targeting MS4A12 variant-1 (MS4A12_siRNA1, target sequence: tccagatcatggttggatt; MS4A12_siRNA2, target sequence: ggttggattgatgcacatt) and negative control (NC) (Ribobio, Guangzhou, China) were transfected into cells with concentration of $60 \mathrm{nmol} / \mathrm{L}$ using Lipofectamine 2000 Transfection Reagent (Invitrogen, USA) according to manufacturer's protocol.

ALP activity assay. Cells were counted and lysed by $1 \%$ TritonX-100 lysis solution. After centrifuged, supernatant was used to analyze ALP activity with Alkaline Phosphatase (AKP/ALP) Detection Kit (NJJCBIO, China) according to manufacturer's protocol. Assays were tested in triplicates and repeated twice.

Cell proliferation assay. Forty-eight hours after siRNA transfection and Sodium butyrate induction $(4 \mathrm{mmol} / \mathrm{l})$, proliferation of the cells were determined with Vita-Orange Cell Viability Reagent (Biotool, USA) according to manufacturer's instructions. All experimental and no-cell control samples had six replicates. Assays were repeated three times [33].

Cell cycle analysis. Forty - eight hours after siRNA transfection and Sodium butyrate induction $(4 \mathrm{mmol} / \mathrm{l}), 5 \times 10^{5}$ cells were fixed with ethanol and stained with propidium iodide for flow cytometry analysis. All assays were done in triplicates and repeated twice.

Cell apoptosis analysis. Forty - eight hours after siRNA transfection and Sodium butyrate induction $(4 \mathrm{mmol} / \mathrm{l}), 5 \times 10^{5}$ cells were stained with Annexin- $\mathrm{V}$ and propidium iodide for flowcytometric apoptosis analysis. Experiments were performed in triplicates and repeated twice.

Western blot. Cultivated cells were harvested and extracted total protein. The total protein lysates were boiled for $5 \mathrm{~min}$ and separated by sodium dodecyl sulfate polyacrylamide gel electrophoresis (SDS-PAGE) on $8 \%$ gels. The proteins were then transferred to a nitrocellulose membrane. The membrane was blocked using 5\% nonfat milk and then incubated with primary antibodies over night at $4{ }^{\circ} \mathrm{C}$. Subsequently, the membranes were washed with TBS-T and incubated with HRP-conjugated secondary antibody at room temperature for $60 \mathrm{~min}$. Membranes were washed and bound antibodies were detected by SuperECL Plus (Thermo pierce, USA). Primary antibodies were anti-E-cadherin (Proteintech, USA) and antiGAPDH (Bioworld, USA).

Phalloidin staining. Cell climbing sheets were fixed by $4 \%$ Poly formaldehyde for $10 \mathrm{~min}$. The cells were washed with PBS and incubated with $0.5 \%$ TritonX-100 for $5 \mathrm{~min}$. Cells then were stained by $100 \mathrm{nmol} / \mathrm{L}$ TRITC-phalloidin (Yeasen, China) for $10 \mathrm{~min}$ at room temperature. Mounting medium containing DAPI was applied directly on top of the cells with cover slip. The slides were analyzed with immunofluorescence microscopy (Olympus DP71, Japan).

Bioinformatics analysis. GEO datasets GSE39582 [34] and GSE38832 [35] including 681 arrays of distinct colon cancer 
A

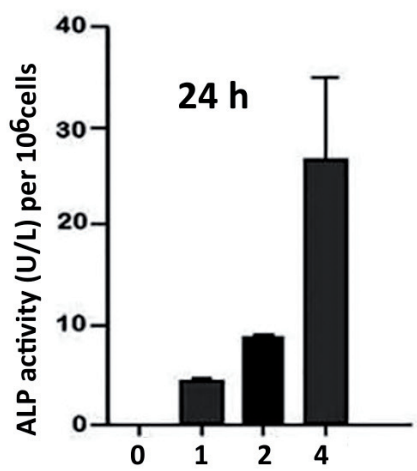

B

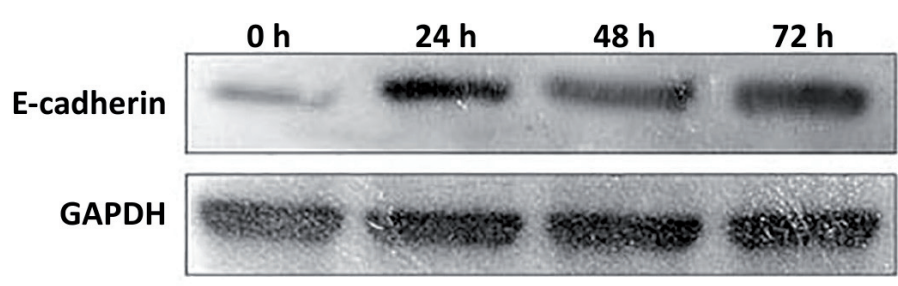

C
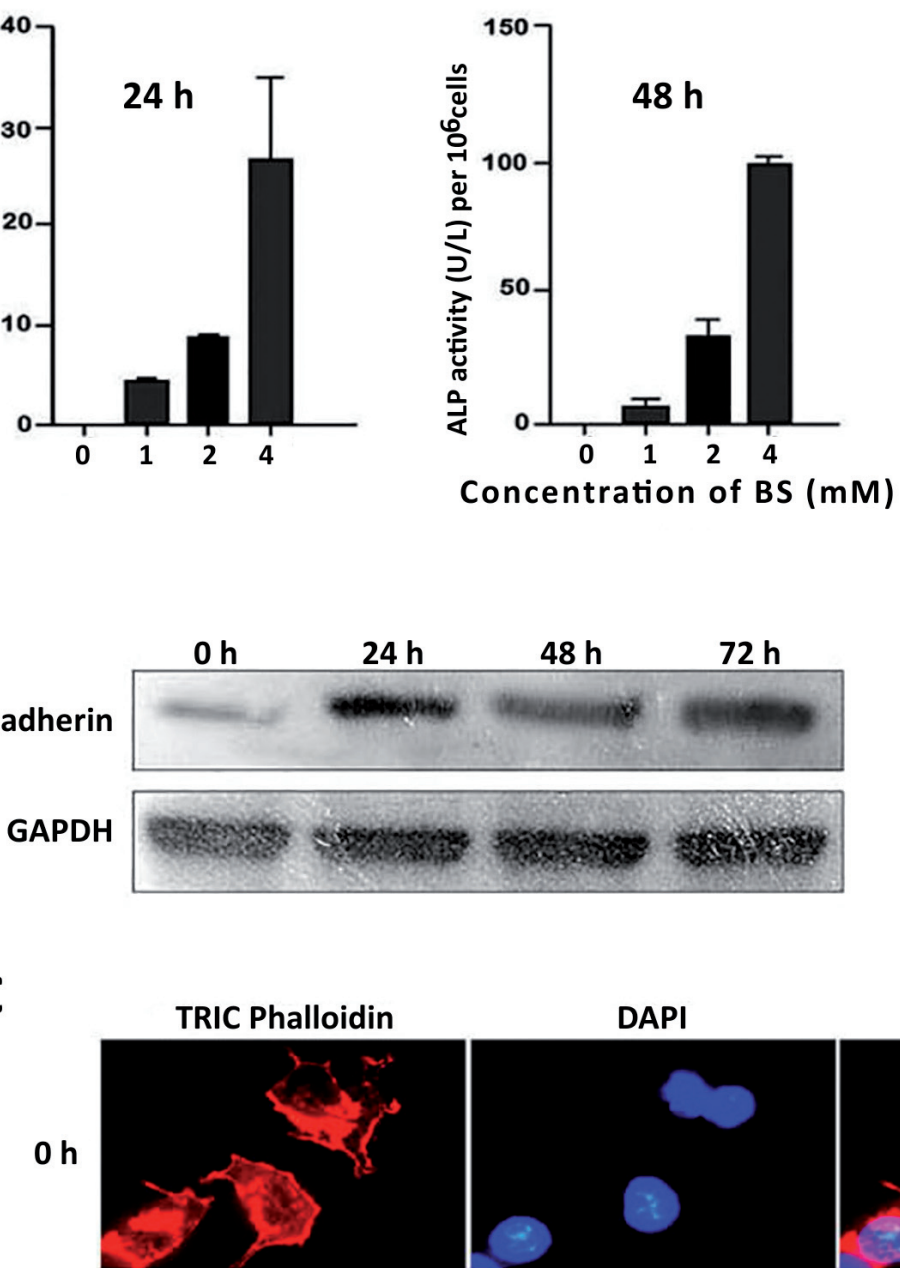

\section{D}
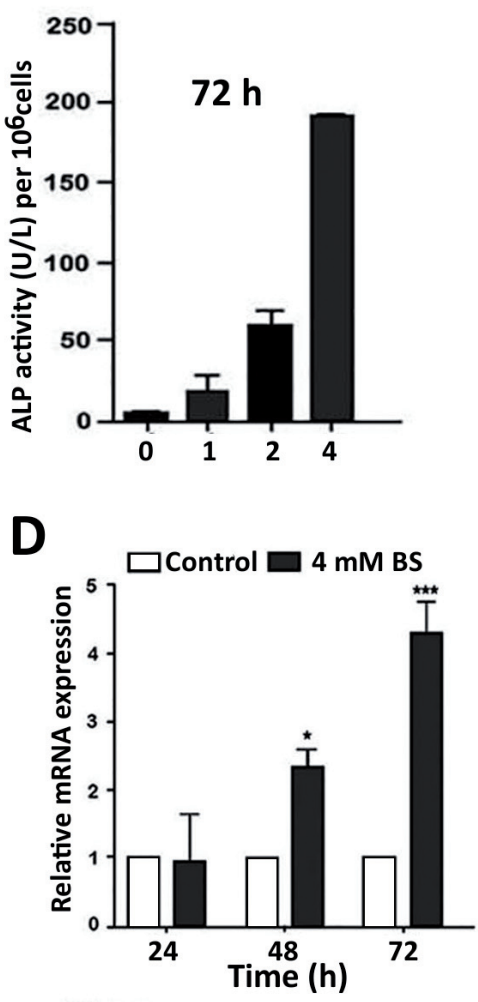

Merge
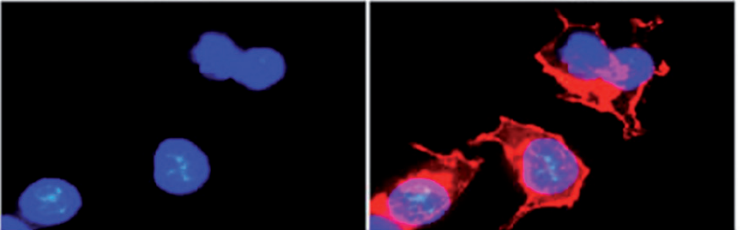

$24 \mathrm{~h}$
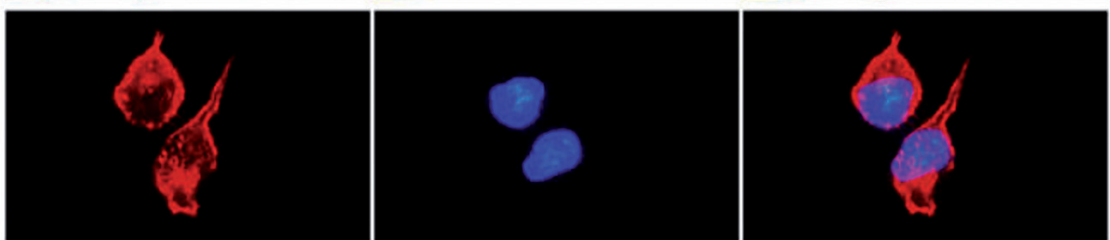

$48 \mathrm{~h}$
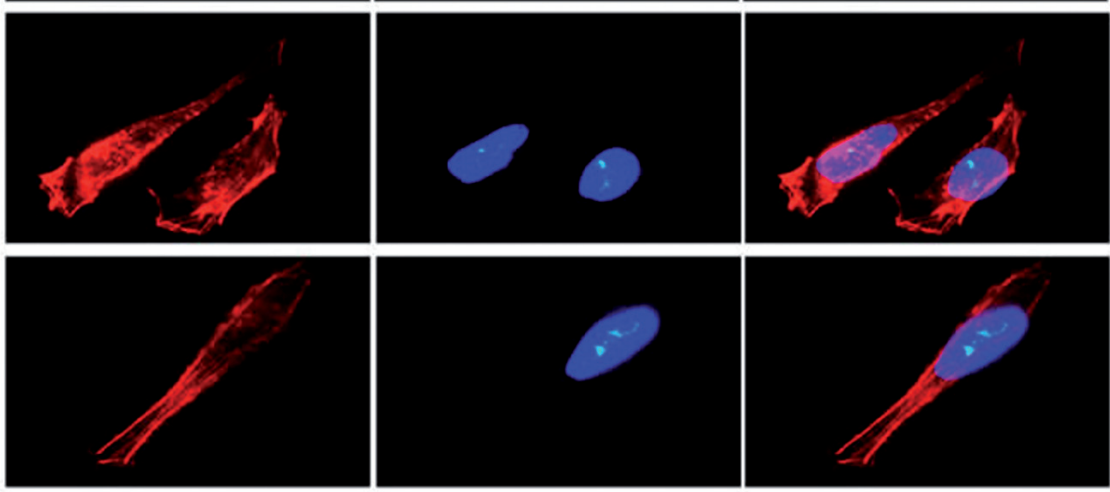

Figure 1. Morphology and differentiation biomarkers changes of butyrate-treated LoVo cells.

A: activity of differentiated marker ALP in LoVo cells elevated with time and concentration of butyrate induction; B: differentiated marker E-cadherin in butyrate-treated $(4 \mathrm{mmol} / \mathrm{L})$ LoVo cells increased with time; C: morphology of butyrate-treated $(4 \mathrm{mmol} / \mathrm{L})$ LoVo cells changed with time, which the morphology of cells changed from irregular or multiple angle shape to shuttle shape (1000x); D: expression of MS4A12 variant1 in butyrate-treated $(4 \mathrm{mmol} / \mathrm{L})$ LoVo cells increased with time; ${ }^{*}: \mathrm{p}<0.05 ;{ }^{* * *}$ : $\mathrm{p}<0.001$. 
samples with clinical and survival information on Affymetrix U133 Plus 2.0 platform were analyzed. All probes intensity signal were normalized using log2[36]. EpCAM were selected as a marker for colon epithelial cells. EpCAM positive samples (Affymetrix probe 201839_s_at >10.05) [41] were allowed to be analyzed. Early stage and advanced stage samples were divided into low-expression and high-expression groups by mean value of MS4A12 (Affymetrix probe 220834_at), respectively. Survival curves were estimated by Kaplan-Meier method, and survival comparisons among groups were assessed with the log-rank test. Multivariate models were computed using Cox's proportional hazards regression.

Statistical analysis. All analyses were carried out using SPSS version 18.0 (SPSS Inc., Chicago, IL, USA). $p$-value < 0.05 was considered statistically significant.

\section{Results}

Sodium butyrate induction differentiation of colon cancer cells. LoVo cells were culture with BS using different concentration ( $1 \mathrm{mmol} / \mathrm{L}, 2 \mathrm{mmol} / \mathrm{L}$ and $4 \mathrm{mmol} / \mathrm{L})$ and time ( $24 \mathrm{~h}, 48 \mathrm{~h}$ and $72 \mathrm{~h}$ ). Activity of differentiated marker ALP increased with concentration and time of butyrate induction (Figure 1A). Specially, when treated BS with concentration of $4 \mathrm{mmol} / \mathrm{L}$, the ALP activity of LoVo cells was rising most obviously. Moreover, when treated BS with concentration of $4 \mathrm{mmol} / \mathrm{L}$, differentiated marker E-cardherin of LoVo cells also increased significantly (Figure 1B). The morphology of BS-treated ( $4 \mathrm{mmol} / \mathrm{L})$ cells changed with time obviously, which changed from irregular or multiple angle shape to shuttle shape (Figure 1C).

MS4A12 variant-1 expression increased during differentiation of colon cancer cells. Two MA4A12 transcripts (MS4A12 variant-1 and MS4A12 variant-2) were evaluated with real time-PCR, while we found expression of MS4A12 variant-1 were significantly rising with butyrate $(4 \mathrm{mmol} / \mathrm{L})$ treated over $48 \mathrm{~h}$ (Figure 1D). While MS4A12 variant-2 was not detected in either butyrate treated LoVo cells or untreated LoVo cells, this result was not showed.
Silence MS4A12 variant-1 inhibited differentiation of colon cancer cells.

The interference rates of two siRNA (MS4A12_siRNA1 and MS4A12_siRNA2) targeting MS4A12 variant-1 were $47.76 \pm 5.57 \%$ and $60.26 \pm 4.92 \%$ (Figure 2A), respectively. After trancsfected with MS4A12 siRNA, the ALP activity of cells with BS treated for $48 \mathrm{~h}$ were significantly inhibited (Figure 2B), and the expression of differentiated marker Ecadherin of the cells was also inhibited (Figure 2C). Moreover, morphology changes induction by BS of the MS4A12 siRNA transfected cells were impaired, which the cells still maintained multiple angle shape (Figure 2D).

Silence of MS4A12 variant-1 against proliferative inhibition of butyrate. Forty-eight hours after transfected with siRNA, the cells survival rate only increased slightly compared to the controls ( $p>0.05)$ (Figure 3 ). As the butyrate having function in inhibiting proliferation of colon cancer cells [37, 38], after silence of MS4A12 variant-1, the cells treated with BS for $48 \mathrm{~h}$ were showed having higher survival rate than that of the controls $(\mathrm{p}<0.05)$ (Figure 3$)$. This result suggested decreasing MS4A12 variant-1 expression in colon cancer cells could against butyrate proliferative inhibition.

Silence of MS4A12 variant-1 against cell cycle arrest of butyrate. After MS4A12 variant-1 expression decreased by siRNA, the cells showed against to BS induction of cell cycle arrest (Figure 4). Compared to the controls, the proportions of $S$ phase cells in interference groups were significantly increased $(\mathrm{p}<0.001)$, while the proportions of G2 phase cells were significantly declining $(\mathrm{p}<0.001)$ (Figure 4$)$.

Silence of MS4A12 variant-1 against butyrate induction apoptosis. After BS treated for $48 \mathrm{~h}$, the MS4A12 siRNA transfected cells showed having fewer apoptosis rate than that of the controls ( $\mathrm{p}=0.021$ ) (Figure 5), which suggested MS4A12 variant-1 silence could resist butyrate inducing apoptosis.

MS4A12 expression related to survivals of colon cancer patients. In the early stage colon cancer without tumor metastasis, we found the expression level of MS4A12 was related to the prognosis. Patients with relative higher level of MS4A12 expression showed a better survivals than that of the patients

Table1. Multivariate analyses with Cox's proportional hazards regression

\begin{tabular}{|c|c|c|c|c|c|}
\hline & $\mathrm{n}$ & Prognostic variable & $\mathrm{HR}^{1}$ & $95 \% \mathrm{CI}^{2}$ & $\mathrm{p}$-value ${ }^{*}$ \\
\hline \multirow{5}{*}{$\begin{array}{l}\text { Early stage } \\
\text { (without tumor metastasis) }\end{array}$} & \multirow[t]{5}{*}{347} & Groups (low/high) & 1.72 & $1.04-2.87$ & 0.036 \\
\hline & & $\mathrm{Age}^{3}$ & 1.04 & $1.02-1.07$ & $<0.001$ \\
\hline & & $\operatorname{Sex}(M / F)^{4}$ & 1.49 & $0.95-2.35$ & 0.073 \\
\hline & & TNM classification (I-II) & 0.66 & $0.26-1.65$ & 0.375 \\
\hline & & Adjuvant chemotherapy & 0.75 & $0.42-1.33$ & 0.321 \\
\hline \multirow{5}{*}{$\begin{array}{l}\text { Advanced stage } \\
\text { (with tumor metastasis) }\end{array}$} & \multirow[t]{5}{*}{334} & Groups (low/high) & 0.89 & $0.58-1.37$ & 0.601 \\
\hline & & $\mathrm{Age}^{3}$ & 1.02 & $1.00-1.04$ & 0.015 \\
\hline & & $\operatorname{Sex}(M / F)^{4}$ & 1.65 & $1.08-2.50$ & 0.020 \\
\hline & & TNM classification (III-IV) & 0.25 & $0.16-0.40$ & $<0.001$ \\
\hline & & Adjuvant chemotherapy & 1.46 & $0.93-2.29$ & 0.104 \\
\hline
\end{tabular}

${ }^{1} \mathrm{HR}$ : hazard ratio; ${ }^{2} \mathrm{CI}$ : confidence interval; ${ }^{3}$ age modeled as a continuous variable; ${ }^{4} \mathrm{M} / \mathrm{F}$ : male vs Female; ${ }^{*} \mathrm{p}$-values $<0.05$ are in bold 

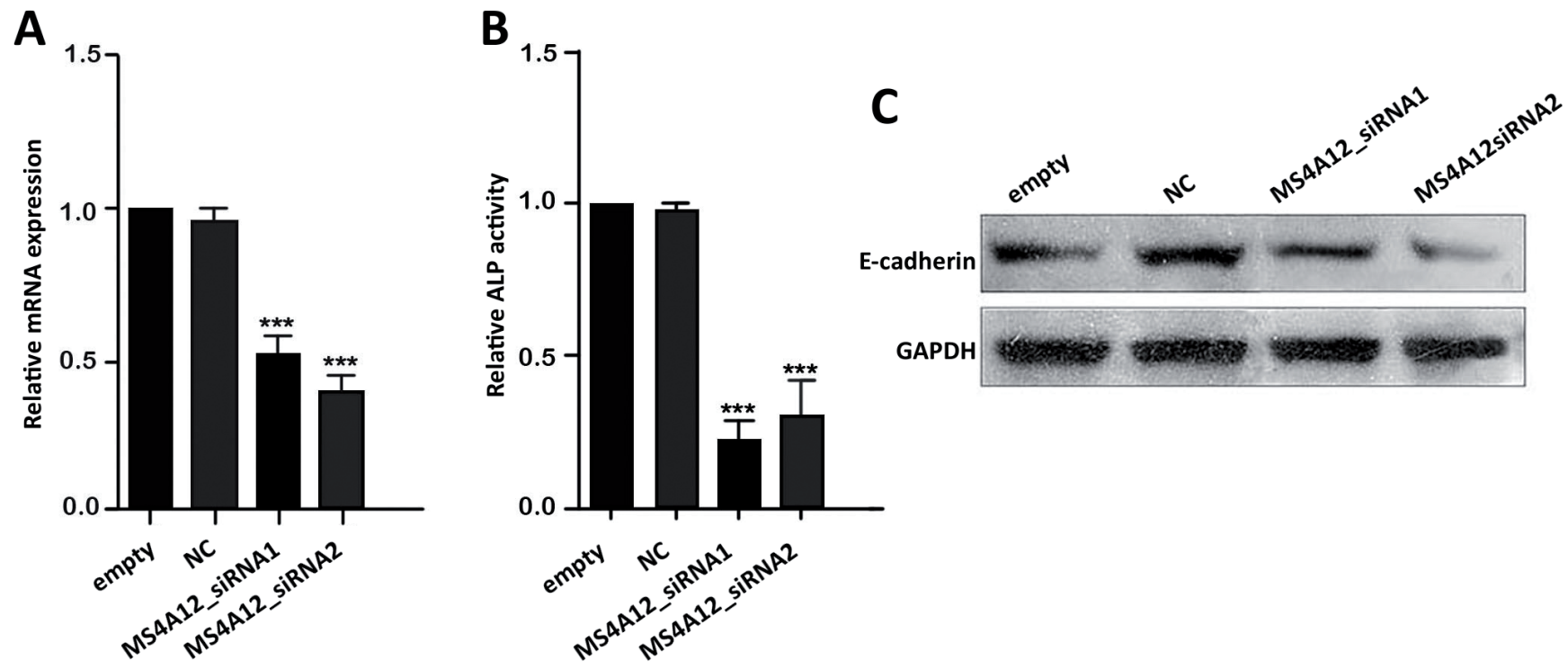

D
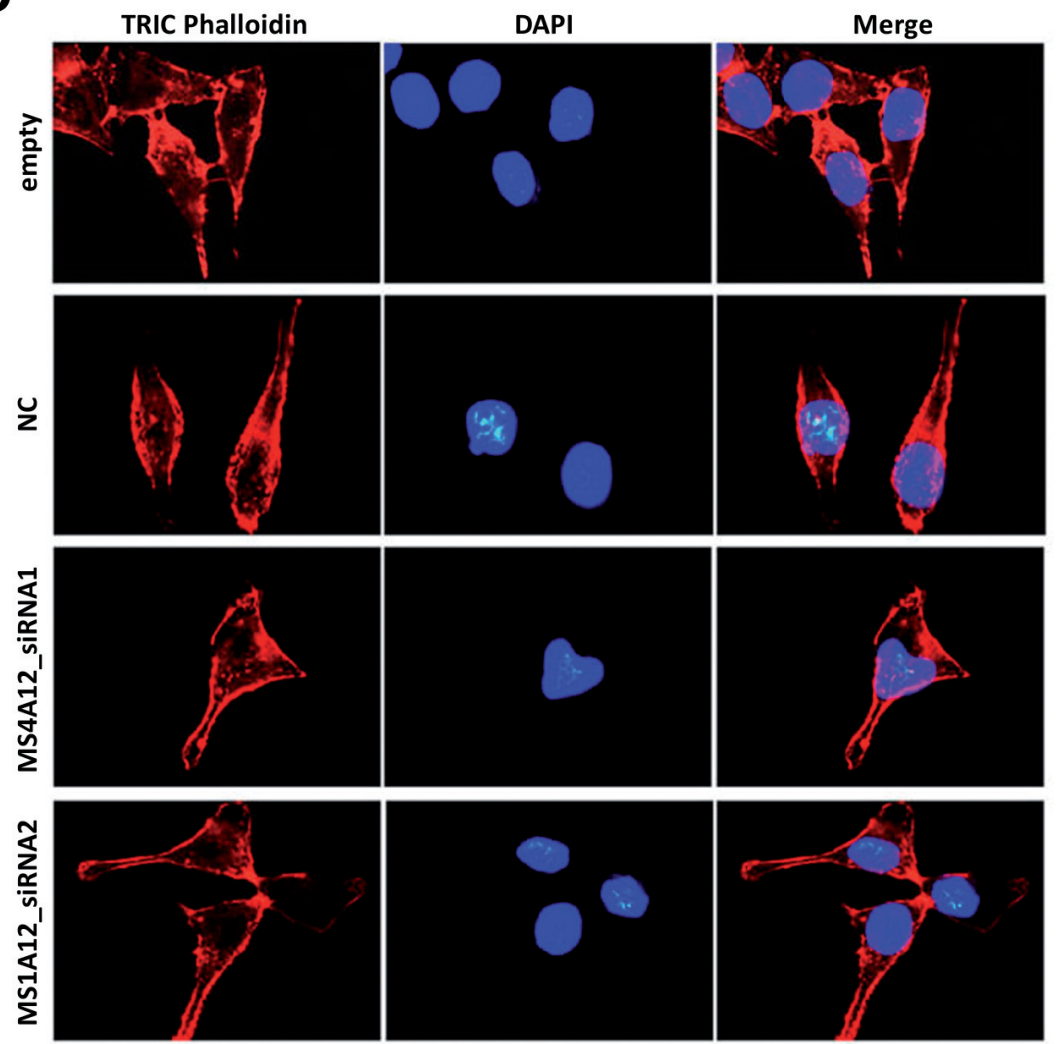

Figure 2. Decreased MA4A12 variant1 expression inhibited differentiation of LoVo cells

A: decreased the expression of MS4A12 varaiant1 by two siRNA; B: elevation of differentiated marker ALP in LoVo cells with butyrate-treated $(4 \mathrm{mmol} / \mathrm{L})$ was inhibited by decrease expression of MS4A12 variant1; C: elevation of differentiated marker E-cadherin in LoVo cells with butyrate-treated $(4 \mathrm{mmol} / \mathrm{L})$ was inhibited by decrease expression of MS4A12 variant1; D: morphology changes in LoVo cells with butyrate-treated $(4 \mathrm{mmol} / \mathrm{L})$ were inhibited by decrease expression of MS4A12 variant1, which in MS4A12_siRNA1/2 group the cells still maintained multiple angle shape; ${ }^{* * *}: \mathbf{p}<0.001$. 


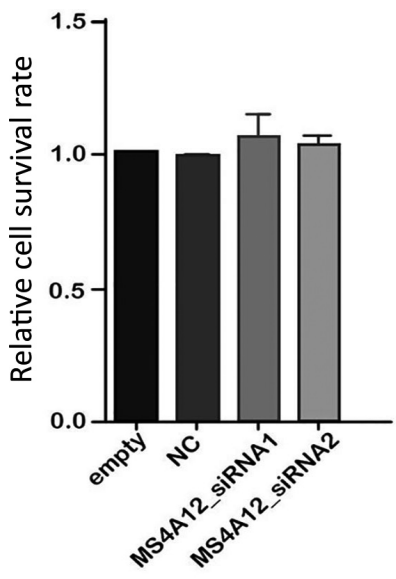

Butyrate untreated

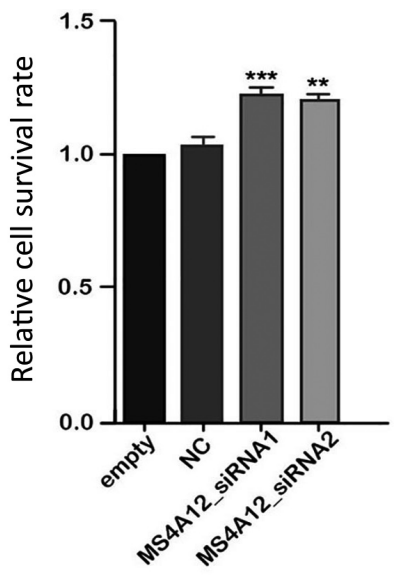

Butyrate treated

Figure 3. silence MS4A12 variant1 resisted proliferative inhibition of butyrate

Note: after silence MS4A12 variant 1 for $48 \mathrm{~h}$, the proliferation of butyrateuntreated LoVo cells did not change significantly, while the proliferation of LoVo cells with butyrate $(4 \mathrm{mmol} / \mathrm{L})$ treated was increased significantly; ${ }^{* *}: \mathrm{p}<0.01 ;{ }^{* * *}: \mathrm{p}<0.001$.

with lower MS4A12 expression ( $\mathrm{p}=0.019)$ (Figure 6A). When considered with other prognostic variables, such as age, sex, TNM classification and adjuvant chemotherapy, MS4A12 expression still showed related to prognosis in the early stage patients (HR: 1.72; $\mathrm{p}=0.036$ ) (Table 1). While in the advanced stage colon cancer with tumor metastasis, MS4A12 expression showed little relevance to patients' survival $(\mathrm{p}=0.601)$ (Figure $6 \mathrm{~B}$ ). When considered with other prognostic variables, including age, sex, TNM classification and adjuvant chemotherapy, MS4A12 expression showed little relevance to prognosis either in the advanced stage patients (HR: 0.89; $\mathrm{p}=0.601$ ) (Table 1).

\section{Discussion}

In this study, we found expression of MS4A12 variant-1 were rising significantly during differentiation of colon cancer cells, which indicates MA4A12 variant-1 could have relevance to the differentiation of colon cancer cells. Furthermore, when MS4A12 variant-1expression decreased by siRNA, the differentiation of colon cancer cells were obviously inhibited, which suggests decreased MS4A12 variant-1 expression in colon cancer cell could inhibit the cell differentiation. Drew [27] found two splice variants of MS4A12 down-regulated in colon adenomatous polyp and carcinoma in same manners, but in situ hybridization better-differentiated tissue showed a higher MS4A12 expression in colon cancer. As is known, most of defined MS4A members have effects on cell differentiation [7, $10]$, so we supposed MS4A12 could relate to differentiation regulation in colon cancer cells.

Interestingly, we also found silence of MS4A12 variant- 1 can against proliferation inhibition, cell cycle arrest and apoptosis
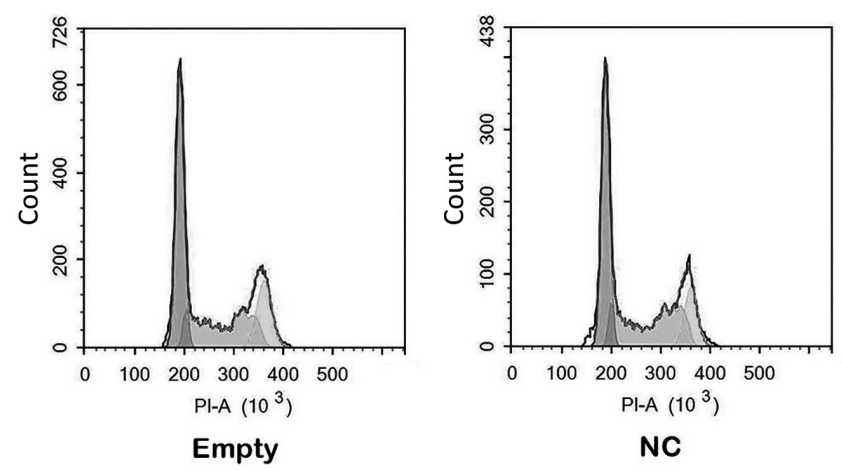

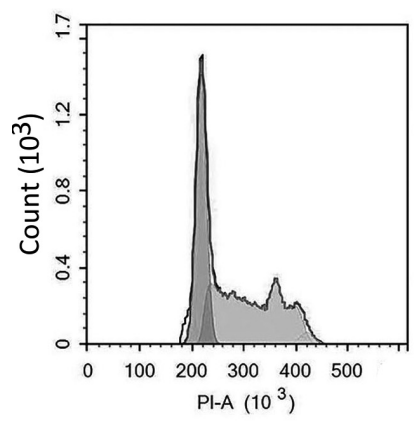

MS4A12_siRNA1

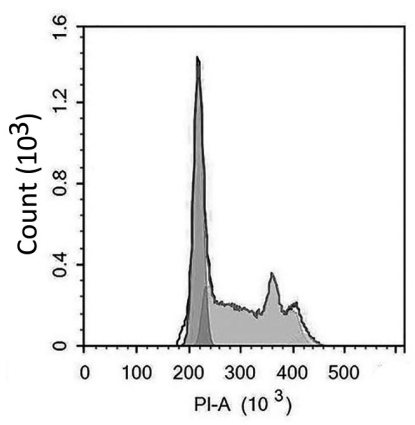

MS4A12_siRNA2

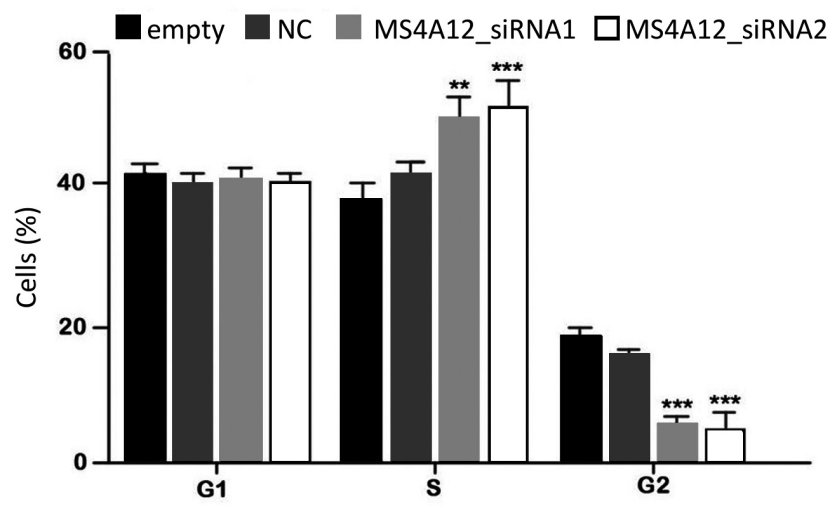

Figure 4. silence MS4A12 variant1 against cell cycle arrest of butyrate. ${ }^{* *}: \mathrm{p}<0.01 ;{ }^{* * *}: \mathrm{p}<0.001$.

induced by sodium butyrate. Butyrate is a short-chain fatty acid that is generated by intestinal bacteria [39]. Butyrate promotes proliferation and provides energy to normal colon epithelium, but in colon cancer cell butyrate shows opposite effects, which inhibiting proliferation, restraining cycle transition, inducing of differentiation and apoptosis [39]. The mechanism of butyrate effects on colon cancer cells could result from its inhibition of histone deacetylase (HDAC). Butyrate inhibiting HDAC results in the direct transcriptional up-regulation of the cyclin-dependent kinase inhibitor p21/Cip1/WAF1 and thereby arrests cell cycling [38]. The cells with proliferation arrest could continuously differentiated and finally apoptosis. 


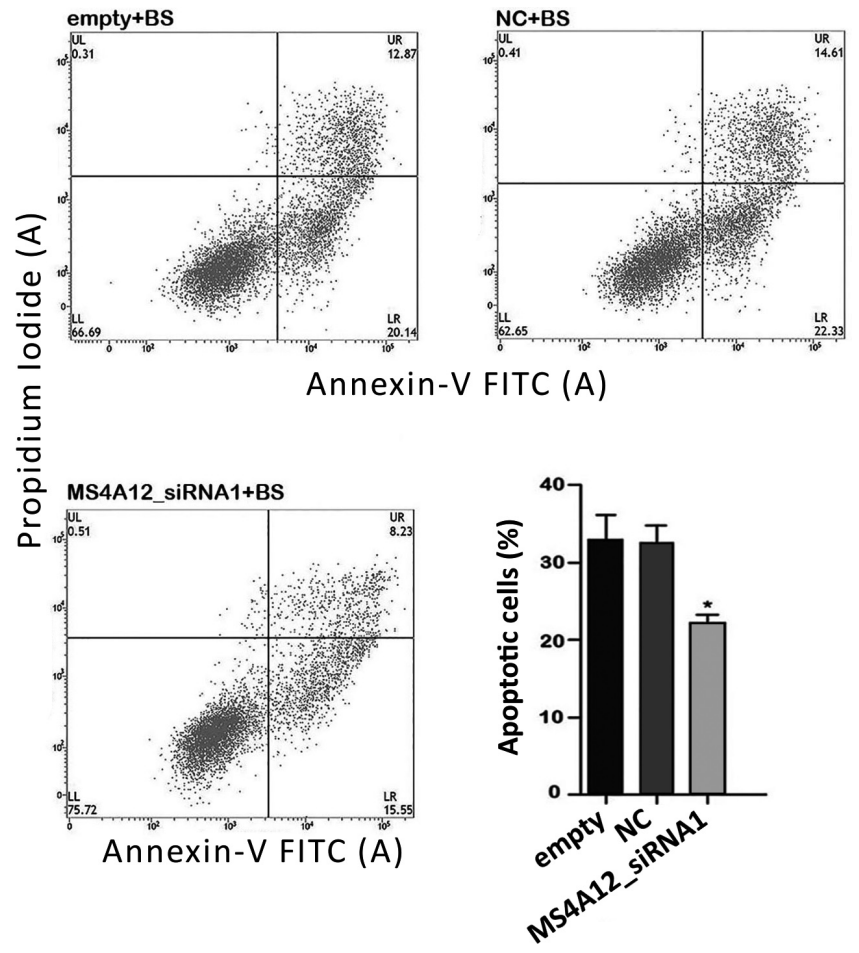

Figure 5. silence MS4A12 variant1 against apoptosis of butyrate induction. ${ }^{*} \mathbf{p}<\mathbf{0 . 0 5}$.

Notably, the action of butyrate is often mediated through Sp1/ $\mathrm{Sp} 3$ binding sites in promoter regions of butyrate-responsive genes [40], and in promoter region of MS4A12 we also found 14 Sp1 binding sites (Figure 7). It indicated that butyrate might regulate MS4A12 expression through its Sp1 binding sites, thus resulting in inhibition of proliferation, arrest of cell cycle, induction of differentiation and apoptosis.
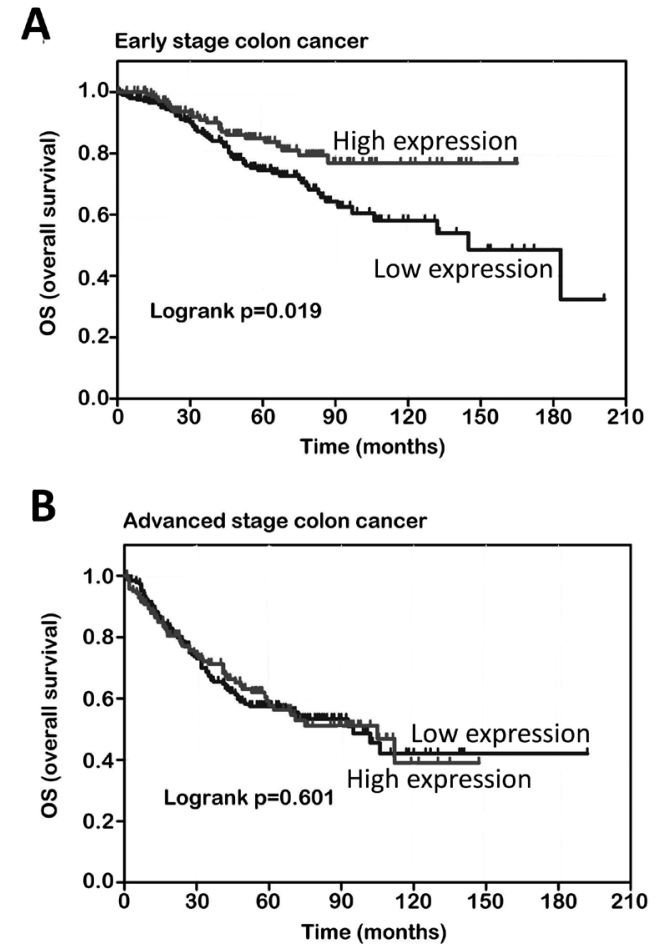

Figure 6. Prognosis value of MS4A12 in the early and advanced stage colon cancer

Besides, the prognostic value of MS4A12 in non-metastasis colon cancer was also detected in the study. It showed that the early stage cancer (without metastasis) patients with relative low MS4A12 expression had a worse survival than that of patients with relative high MS4A12 expression. Dalerba [41] found a KRT20/MS4A12 two gene model to predict prognosis of colon cancer, but in this study we noticed only using

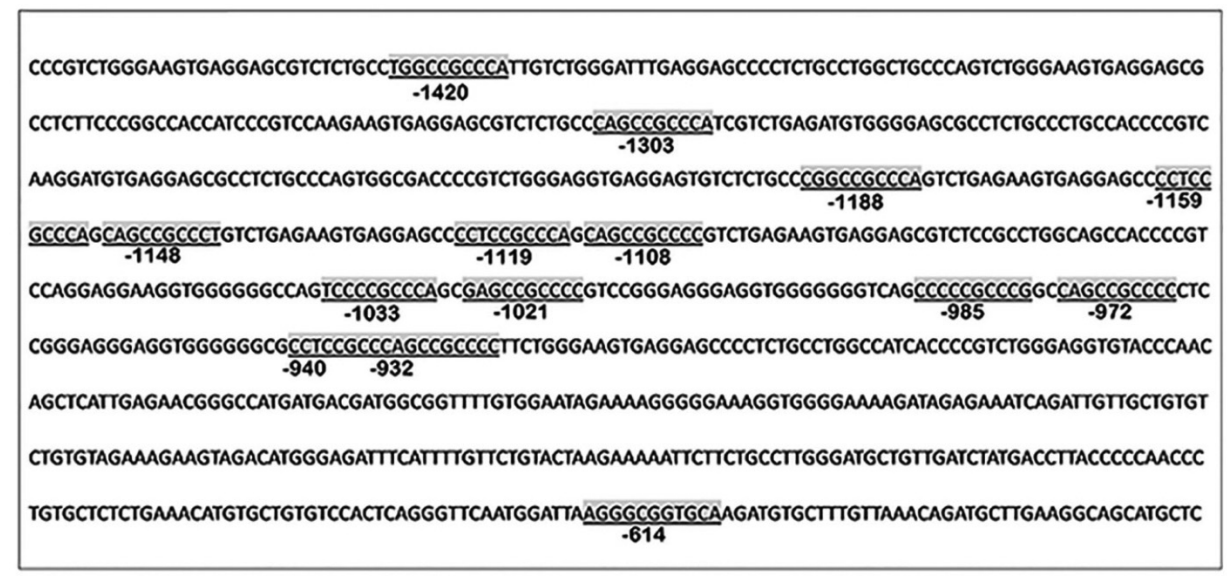

Figure 7. Sp1 binding sites on the promoter region of MS4A12 gene

There are 14 Sp1 binding sites on MS4A12 promoter region. The promoter sequence of MS4A12 obtained from the UCSC Genome Browser (http://genome.ucsc.edu). The analysis was performed using the ALGGEN PROMO (http://alggen.lsi.upc.es/cgi-bin/promo_v3/promo/promoinit. cgi?dirDB=TF_8.3). 
MS4A12 can predict prognosis in early stage colon cancer patient. It suggested MS4A12 could mainly relate to malignancy of non-metastasis tumor and have little prognosis value of metastasis colon tumor. Therefore, MS4A12 supposed to be a risk classification marker for early stage colon cancer.

Acknowledgements: This work was supported by the Fundamental Research Funds of the Central Universities of Central South University.

\section{References}

[1] ZEUNER A, TODARO M, STASSI G, DE MARIA R. Colorectal cancer stem cells: from the crypt to the clinic. Cell Stem Cell 2014; 15: 692-705. https:/doi.org/10.1016/j. stem.2014.11.012

[2] ISHIBASHI K, SUZUKI M, SASAKI S, IMAI M. Identification of a new multigene four-transmembrane family (MS4A) related to CD20, HTm4 and beta subunit of the high-affinity IgE receptor. Gene 2001; 264: 87-93. https:/doi.org/10.1016/ $\underline{\mathrm{S} 0378-1119(00) 00598-9}$

[3] BOUCHEIX C, RUBINSTEIN E. Tetraspanins. Cell Mol Life Sci 2001; 58: 1189-1205. https:/doi.org/10.1007/ $\underline{\text { PL00000933 }}$

[4] LIANG Y, BUCKLEY TR, TU L, LANGDON SD, TEDDER TF. Structural organization of the human MS4A gene cluster on Chromosome 11q12. Immunogenetics 2001; 53: 357-368. https:/doi.org/10.1007/s002510100339

[5] ZUCCOLO J, BAU J, CHILDS SJ, GOSS GG, SENSEN CW et al. Phylogenetic analysis of the MS4A and TMEM176 gene families. PLoS One 2010; 5: e9369. https:/doi.org/10.1371/ journal.pone.0009369

[6] LIANG Y, TEDDER TF. Identification of a CD20-, FcepsilonRIbeta-, and HTm4-related gene family: sixteen new MS4A family members expressed in human and mouse. Genomics 2001; 72: 119-127. https:/doi.org/10.1006/geno.2000.6472

[7] GOLAY JT, CLARK EA, BEVERLEY PC. The CD20 (Bp35) antigen is involved in activation of $\mathrm{B}$ cells from the G0 to the G1 phase of the cell cycle. J Immunol 1985; 135: 3795-3801.

[8] CRUSE G, KAUR D, LEYLAND M, BRADDING P. A novel FcepsilonRIbeta-chain truncation regulates human mast cell proliferation and survival. FASEB J 2010; 24: 4047-4057. https:/doi.org/10.1096/fj.10-158378

[9] DONATO JL, KO J, KUTOK JL, CHENG T, SHIRAKAWA $\mathrm{T}$ et al. Human HTm4 is a hematopoietic cell cycle regulator. J Clin Invest 2002; 109: 51-58. https:/doi.org/10.1172/ $\underline{\mathrm{LCI} 0214025}$

[10] GINGRAS MC, LAPILLONNE H, MARGOLIN JF. CFFM4: a new member of the CD20/FcepsilonRIbeta family. Immunogenetics 2001; 53: 468-476. https:/doi.org/10.1007/ $\underline{\text { s002510100345 }}$

[11] EON KL, LEFFLER M, MACKAY GA, HULETT MD. The MS4A family: counting past 1, 2 and 3. Immunol Cell Biol 2016; 94: 11-23. https:/doi.org/10.1038/icb.2015.48

[12] TEDDER TF, STREULI M, SCHLOSSMAN SF, SAITO H. Isolation and structure of a cDNA encoding the B1 (CD20) cell-surface antigen of human B lymphocytes. Proc Natl
Acad Sci USA 1988; 85: 208-212. https:/doi.org/10.1073/ pnas.85.1.208

[13] WILLIAMSON JM, GRIGOR I, SMITH ME, HOLGATE CS, O'BRIEN CJ et al. Ploidy, proliferative activity, cluster differentiation antigen expression and clinical remission in high-grade non-Hodgkin's lymphoma. Histopathology 1987; 11: 1043-1054. https:/doi.org/10.1111/j.1365-2559.1987. tb01844.x

[14] SEYFIZADEH N, SEYFIZADEH N, HASENKAMP J, HUERTA-YEPEZ S. A molecular perspective on rituximab: A monoclonal antibody for B cell non Hodgkin lymphoma and other affections. Crit Rev Oncol Hematol 2016; 97: 275-290. https:/doi.org/10.1016/j.critrevonc.2015.09.001

[15] EICHHORST B, CRAMER P, HALLEK M. Initial therapy of chronic lymphocytic leukemia. Semin Oncol 2016; 43: 241-250. https:/doi.org/10.1053/j.seminoncol.2016.02.005

[16] CRAGG MS, WALSHE CA, IVANOV AO, GLENNIE MJ. The biology of CD20 and its potential as a target for $\mathrm{mAb}$ therapy. Curr Dir Autoimmun 2005; 8: 140-174. https:/doi. org/10.1159/000082102

[17] CLARK EA, SHU G. Activation of human B cell proliferation through surface Bp35 (CD20) polypeptides or immunoglobulin receptors. J Immunol 1987; 138: 720-725.

[18] LOKEN MR, SHAH VO, DATTILIO KL, CIVIN CI. Flow cytometric analysis of human bone marrow. II. Normal B lymphocyte development. Blood 1987; 70: 1316-1324.

[19] ISHIBASHI K, SUZUKI M, SASAKI S, IMAI M. Identification of a new multigene four-transmembrane family (MS4A) related to CD20, HTm 4 and beta subunit of the high-affinity IgE receptor. Gene 2001; 264: 87-93. https:/doi.org/10.1016/ S0378-1119(00)00598-9

[20] OKAYAMA Y, MATSUDA A, KASHIWAKURA JI, SASAKISAKAMOTO T, NUNOMURA S et al.: Highly expressed cytoplasmic FcepsilonRIbeta in human mast cells functions as a negative regulator of the FcRgamma-mediated cell activation signal. Clin Exp Allergy 2014; 44: 238-249. https:/doi. org/10.1111/cea.12210

[21] MA J, YU JT, TAN L. MS4A Cluster in Alzheimer's Disease. Mol Neurobiol 2015; 51: 1240-1248. https:/doi.org/10.1007/ s12035-014-8800-Z

[22] YE L, YAO XD, WAN FN, QU YY, LIU ZY et al. MS4A8B promotes cell proliferation in prostate cancer. Prostate 2014; 74: 911-922. https:/doi.org/10.1002/pros.22802

[23] BANGUR CS, JOHNSON JC, SWITZER A, WANG YH, HILL B et al. Identification and characterization of L985P, a CD20 related family member over-expressed in small cell lung carcinoma. Int J Oncol 2004; 25: 1583-1590. https:/doi. org/10.3892/ijo.25.6.1583

[24] KOSLOWSKI M, SAHIN U, DHAENE K, HUBER C, TURECI O. MS4A12 is a colon-selective store-operated calcium channel promoting malignant cell processes. Cancer Res 2008; 68: 3458-3466. https:/doi.org/10.1158/0008-5472. CAN-07-5768

[25] MICHEL J, SCHONHAAR K, SCHLEDZEWSKI K, GKANIATSOU C, STICHT C et al. Identification of the novel differentiation marker MS4A8B and its murine homolog MS4A8A in colonic epithelial cells lost during neoplastic 
transformation in human colon. Cell Death Dis 2013; 4: e469. https:/doi.org/10.1038/cddis.2012.215

[26] KOSLOWSKI M, TURECI O, HUBER C, SAHIN U. Selective activation of tumor growth-promoting Ca2+ channel MS4A12 in colon cancer by caudal type homeobox transcription factor CDX2. Mol Cancer 2009; 8: 77. https:/doi.org/10.1186/14764598-8-77

[27] DREW JE, FARQUHARSON AJ, MAYER CD, VASE HF, COATES PJ et al. Predictive gene signatures: molecular markers distinguishing colon adenomatous polyp and carcinoma. PLoS One 2014; 9: e113071. https:/doi.org/10.1371/journal. pone. 0113071

[28] CRUSE G, BEAVEN MA, ASHMOLE I, BRADDING P, GILFILLAN AM et al. A truncated splice-variant of the FcepsilonRIbeta receptor subunit is critical for microtubule formation and degranulation in mast cells. Immunity 2013; 38: 906-917. https:/doi.org/10.1016/j.immuni.2013.04.007

[29] GAMONET C, BOLE-RICHARD E, DELHERME A, AUBIN F, TOUSSIROT E et al. New CD20 alternative splice variants: molecular identification and differential expression within hematological B cell malignancies. Exp Hematol Oncol 2015; 5: 7. https:/doi.org/10.1186/s40164-016-0036-3

[30] HENRY C, DESCHAMPS M, ROHRLICH PS, PALLANDRE JR, REMY-MARTIN JP et al. Identification of an alternative CD20 transcript variant in B-cell malignancies coding for a novel protein associated to rituximab resistance. Blood 2010; 115: 2420-2429. https:/doi.org/10.1182/blood-200906-229112

[31] HERZ F, HALWER M. Modulation of alkaline phosphatases in LoVo, a human colon carcinoma cell line. Biochim Biophys Acta 1989; 1013: 259-265. https:/doi.org/10.1016/0167-4889(89)90144-4

[32] HERZ F, HALWER M. Differential effects of sodium butyrate and hyperosmolality on the modulation of alkaline phosphatases of LoVo cells. Exp Cell Res 1990; 188: 50-54. https:/ doi.org/10.1016/0014-4827(90)90276-G

[33] SONAWANE P, CHO HE, TAGDE A, VERLEKAR D, YU $\mathrm{AL}$ et al. Metabolic characteristics of 13-cis-retinoic acid (isotretinoin) and anti-tumour activity of the 13-cis-retinoic acid metabolite 4-oxo-13-cis-retinoic acid in neuroblastoma. Br J Pharmacol 2014; 171:5330-5344. https:/doi.org/10.1111/ bph.12846

[34] MARISA L, DE REYNIES A, DUVAL A, SELVES J, GAUB MP et al. Gene expression classification of colon cancer into molecular subtypes: characterization, validation, and prognostic value. PLoS Med 2013; 10: e1001453. https:/doi. org/10.1371/journal.pmed.1001453

[35] TRIPATHI MK, DEANE NG, ZHU J, AN H, MIMA S et al. Nuclear factor of activated T-cell activity is associated with metastatic capacity in colon cancer. Cancer Res 2014; 74: 6947-6957. https:/doi.org/10.1158/0008-5472.CAN-14$\underline{1592}$

[36] TAGDE A, RAJABI H, STROOPINSKY D, GALI R, ALAM $\mathrm{M}$ et al. MUC1-C induces DNA methyltransferase 1 and represses tumor suppressor genes in acute myeloid leukemia. Oncotarget 2016; Jun 1, doi: 10.18632/oncotarget.9777. [Epub ahead of print] https:/doi.org/10.18632/oncotarget. 9777

[37] COMALADA M, BAILON E, DE HARO O, LARA-VILLOSLADA F, XAUS J et al. The effects of short-chain fatty acids on colon epithelial proliferation and survival depend on the cellular phenotype. J Cancer Res Clin Oncol 2006; 132: 487-497. https:/doi.org/10.1007/s00432-006-0092-x

[38] TANG Y, CHEN Y, JIANG H, NIE D. The role of short-chain fatty acids in orchestrating two types of programmed cell death in colon cancer. Autophagy 2011; 7: 235-237. https:/ doi.org/10.4161/auto.7.2.14277

[39] LEONEL AJ, ALVAREZ-LEITE JI. Butyrate: implications for intestinal function. Curr Opin Clin Nutr Metab Care 2012; 15: 474-479. https:/doi.org/10.1097/MCO.0b013e32835665fa

[40] DAVIE JR. Inhibition of histone deacetylase activity by butyrate. J Nutr 2003; 133: 2485S-2493S.

[41] DALERBA P, KALISKY T, SAHOO D, RAJENDRAN PS, ROTHENBERG ME et al. Single-cell dissection of transcriptional heterogeneity in human colon tumors. Nat Biotechnol 2011; 29: 1120-1127. https:/doi.org/10.1038/nbt.2038 